\title{
European Values and the Chinese Factor
}

\section{The Problem of the European Union's Common Stance on China and EU Countries' Bilateral Relations with It}

\section{Natalia B. Pomozova}

\author{
Natalia B. Pomozova \\ Russian State University for the Humanities, Moscow, Russia \\ School of History, Political Science and Law \\ Senior Lecturer \\ ResearcherID: AAE-3313-2020 \\ ORCID: 0000-0002-9981-0593 \\ E-mail:npomozova@mail.ru \\ Address: 21 Visokaya Str., Moscow, 115533, Russia \\ DOI: $10.31278 / 1810-6374-2020-18-1-180-196$
}

\begin{abstract}
The liberal values lying at the core of the European continent's integration into the European Union (EU) are being put to the test by new factors, particularly the consistent and all-around strengthening of China. Europe's attitude towards this new global "center of power" and, in particular, its Belt and Road Initiative, increasingly demonstrates the fragility of the existing system of values in EU countries, and its declining effectiveness. The article considers some contradictory foreign policy approaches towards China assumed by Great Britain, Germany, France, and Italy as the key EU countries in the context of the traditional European values and economic benefits that cooperation with China implies, including in terms of the theory of social constructivism. The author makes an assumption that if EU countries carry out a common policy towards China, they will probably be able to preserve their basic liberal values (albeit in a somewhat modified form) as a unifying factor and their main foreign policy tool. However, a rush of EU countries
\end{abstract}


towards solving internal socioeconomic problems by developing bilateral relations with China, may seriously rock the entire union in the long run.

Keywords: European Union, China, Russia, pan-European values, international relations, Community of Common Destiny with Mankind

urrently, the European Union is perhaps the most efficient
integration association in the world. Its own borders, common
citizenship, collective institutions, and single currency are its distinctive features and invaluable assets. But it is certainly based on something more than what once brought some of the European countries together. It is a set of basic moral and ethical guidelines, democratic values, and in fact, the "liberal idea" in its widest sense. Although the UK, one of the EU's most important countries, has recently left the Union, there is no good reason to expect a collapse of the European Union any time soon.

However, European affairs clearly show that pan-European values do not stand up to the challenges facing, paradoxically as it may seem, the most economically developed countries in the first place.

A serious blow came from migration, which has exposed acute contradictions within European society on issues of identity, tolerance, "equality and brotherhood." In 2014-2015, when hundreds of thousands of migrants flooded Europe, the governments of some Central and Eastern European countries demonstrated their unwillingness to act in the spirit of humanistic rhetoric exuded by German Chancellor Angela Merkel. The turning point came when populists from Central Europe spoke of their independence not only from Brussels but also from Western liberalism (Krastev and Holmes, 2019a).

The reaction followed quickly, causing irreparable damage to the entire system of political and humanitarian relations that was embedded in the idea of a united Europe by its founders. The classic well-balanced "left-center-right" model is going down the drain, with right-wing and far-right populists taking the stage in European politics, expressing, as it has turned out, the opinion of a substantial part of voters. 
The Italian League, not so long ago considered a marginal party, is putting European humanism through a series of harsh trials. The Alternative for Germany, the French National Rally, formerly National Front, stigmatized by the European political class as a fascist party, the Freedom Party of Austria, branded similarly, and a number of others are without a doubt proponents of the European establishment, which advocates the current idea of defending their countries' public interests, and in reality undisguised national egoism contrary to pan-European values.

At a meeting with the French ambassadors on August 29, 2019, obviously trying to snatch leadership in crafting European ideology away from the German chancellor, Emanuel Macron openly declared, in an unprecedented twist of discourse among top-level European politicians, that we live in a bipolar world where there are only two centers-the United States and China-and that Europe has no other choice but to fit into this scheme of things, otherwise European civilization may simply collapse (Macron, 2019). This statement can be considered a blow to the entire system of European worldview, which was laid down by the post-war settlement arrangements and considered immutable for a long time.

Interestingly, in the same speech Macron said that European and Chinese values were direct opposites of each other. And this sent a second shock wave across liberal Europe, since the Western European system of values is obviously experiencing China's critical influence fraught with its subsequent transformation.

\section{CHINA'S RATIONALE OFFERED TO THE WORLD}

According to the theory of social constructivism, people act towards objects, including other actors, on the basis of meaning that the objects have for them (Wendt, 1992, pp. 391-425). The fact that China is perceived in the European Union, on the one hand, as a threat and, on the other hand, as a source of economic benefits predetermines the participating countries' actions with regard to Beijing, which often have a dual nature.

China's highly ambitious concept of the Community of Common Destiny with Mankind implies replacing the "Western" model of 
international relations established after the end of the Cold War with a new one since the existing system has certain weaknesses, including the fact that Western values in the traditional sense are not viable.

In analyzing Beijing's current foreign policy from the perspective of constructivism, whose followers assume that discursive power in international relations is no less important than military power, one can conclude that China is committed to Jurgen Habermas' approach, according to which power methods can be excluded from international relations and replaced with discursive ones (Alekseeva, 2014, pp.4-12).

For example, S. Pestsov notes: "In promoting the Belt and Road initiative, China is guided by the importance of communication and dialogue for the successful implementation of this initiative and by the need to build appropriate discourse that allows neutralizing the damage from erroneous, in its opinion, interpretations and possible negative connotations" (Pestsov, 2017, pp.155-164).

The concept of the Community of Common Destiny with Mankind is also an example of the use of discursive power based on values as China's main foreign policy instrument. Professor Wu Xiangdong of Beijing Normal University believes that the Community of Common Destiny with Mankind is not only a community of interests, but also a community of values. This concept implies respect for values and cultural diversity, and states that different cultures and values can come into contact, engage in dialogue and learn from each other, strive for mutual understanding through exchanges and dialogues, and integrate. The Belt and Road Initiative means that people around the world are closely connected with each other not only economically, politically and socially, but also in terms of values and cultures (Wu, 2017).

In his speech at the 19th Congress of the Communist Party of China, President Xi Jinping twice used the phrase "a new type of international relations," and concluded by saying that his country intended to "put Chinese wisdom and strength into global governance" (Pomozova, 2018, p.157). This is the main message the Chinese leadership is sending to the world public.

As China became economically and politically stronger, it formulated its own "core socialist values," contrasting them with the 
Western system of values. The main difference is in priorities. In China, it is "the state-society-individual." "Responsibility precedes freedom, duty comes before rights, society stands above the individual, harmony takes precedence over conflict" (Lomanov, 2015). In this sense it is possible to talk about some "reincarnation" of the "managed," expert democracy concept proposed by Western political scientists and futurists in the 1970s (Litvak, 2010 pp.3-11).

Although not all countries view Chinese values as a real alternative to the existing universal values, China is actively using them as an instrument of diplomacy, offering its own vision of how the system of international relations should develop (Grachikov, 2019, pp. 83-93).

Being part of China's global foreign policy vision, the New Silk Road project is a serious challenge to the system of common European values, exposing their vulnerability in the face of presentday realities where economic gains rise above principles. The strong point of the Chinese concept is that it does not encroach upon the political system of participating states. This clearly gives the Chinese foreign policy approach an advantage over the American one, but does not spare it the criticism of skeptics who question the sincerity of Beijing's altruistic intentions.

According to the constructivist theory, the actions of states are determined by institutions and the norms of international life, which, in turn, impact the socialization and activities of states, resulting in interaction between agents and structures.

China's growing multi-vector power is pushing the European Union towards developing common rules of conduct with regard to Beijing for all of its member countries to abide by in order to contain China's strengthening as much as possible.

The analysis of the policy major EU countries have recently been pursuing with regard to China indicates that it conforms to the constructivist approach, which is underlain by the actors' pragmatic and practical mode of action (Alekseeva, 2010, pp. 4-10). For example, Europeans are trying to engage with China on a bilateral basis in order to maximize the benefits for their respective states, thus putting them above pan-European solidarity. 


\section{GREAT BRITAIN}

The UK's policy towards China is two-pronged, balancing between containing Beijing's growing power and, at the same time, boosting trade and investment cooperation with it.

Thus, the National Security Strategy and Strategic Defense 2015 considers China solely as an economic partner and makes no reference to it whatsoever as a revisionist power (unlike Russia which it claims is seeking to undermine the existing international order) (National Security Strategy, 2015). Such rhetoric is driven by the UK's desire to take trade and economic cooperation with China to a new level, making it the second main export destination for the country. It is expected that this will also be facilitated by Britain's withdrawal from the European Union, as a result of which it will be able to pursue a more independent foreign policy. For example, the Global Britain concept has identified the Indo-Pacific region as one of its three priorities.

And yet, the British expert and political community regularly voices concern about China's increased presence on the European continent. For example, in 2019, the Royal United Services Institute for Defense and Security Studies issued an analytical paper entitled "The China-UK Relations. Where to Draw a Border between Influence and Interference?" (Patron, 2019), which examines threats and challenges from China (soft power tools: "discussion platforms," Confucius Institute, influence on the media, freedom of speech, espionage, threat to strategic national infrastructure, technological threats), and gives some recommendations on how to handle these challenges. English parliamentarians openly express concern over the shift in Britain's China policy in favor of economic priorities over UK strategic interests, values and national security (House of Commons Foreign Affairs Committee, 2019). In analyzing the evolution of London's discourse vis-a-vis Beijing, the "American" factor needs to be taken into account as well, as it has a serious impact on the UK foreign policy. In fact, the U.S. has been pursuing "aggressive" policy with regard to China after Donald Tramp's election, with the UK following suit.

However, despite the deterioration of China's image in UK foreign policy discourse, Britain is the fourth largest importer from 
China; it was the first in the Group of Seven to have joined the Asian Infrastructure Investment Bank in 2015 and it keeps its market open to Chinese investment. In general, China participates in the UK economy in various ways, but the British expert community views China as a country that pursues its own interests rather than seeking to undermine existing values.

Thus, Tim Summers believes that China is a "direct challenge to liberal democracy and Europe's values and interests." But there is scant evidence of such an "authoritarian advance" in the case of the UK (Summers, 2018, p. 90).

If the UK's stance on China is considered from the point of view of constructivist theory, one can conclude that there has been a negative change in the perception of China's identity. However, it has no direct relation to the dynamics of economic cooperation between the two countries. On the contrary, due to external factors (Brexit, China's "trade war" with the U.S.) it can be expected to strengthen, which will once again underscore the pragmatic side of London's foreign policy approach.

\section{GERMANY}

Germany, the EU's unconditional leader, is the world's fourth largest and Europe's number one trading partner of China, and the main center of attraction for Chinese investments on the European continent.

Germany's international policy is in line with the EU underlying principles and, at first glance, matches the EU's foreign policy strategy: strengthening democracy, the rule of law, and human rights around the world, as well as adhering to the international order based on the post-Cold-War rules. The historical legacy predetermined Germany's commitment to promoting liberal democratic values in domestic and foreign policy. Germany also views these values as its political interests, perceiving them as the basis for lasting peace and stable development. European cohesion and integration are also central to Berlin's foreign policy.

But the promotion of these principles in relations with China is complicated by Germany's need to cooperate with Beijing on economic 
and strategic issues. China has been Germany's largest trading partner since 2016. In addition, in view of the changing transatlantic relationship, Germany places greater emphasis on cooperation with China in the field of global governance, from protecting the World Trade Organization (WTO) to dealing with climate change. As a result, discussions in German political circles on how to balance economic, strategic and values interests become increasingly regular.

Recently, these debates have entered a new phase due to the consolidated view shared by German political elites that China will not become "like us," that is, it will not accept Western liberal values. This view, however, is in stark contrast to the Foreign Office Concept of 2002, which states that the German government will support China's transition to an open society based on respect for human rights (Federal Foreign Office, 2002).

China is a key market for major German companies which have about 700 subsidiaries, included in the DAX-30 index, working there.

In addition to mutual economic interests, cooperation in the field of high technology is perhaps the main aspect of German-Chinese relations. In Hanover on April 22, 2018, Chancellor Merkel spoke publicly about the need to win the fight with China for leadership in the field of artificial intelligence (Merkel, 2018).

High technologies are a highly sensitive aspect of German-Chinese relations. On the one hand, this is a strategic area in which Berlin has significant achievements and which it wants to protect from data leakage abroad; on the other hand, China, too, has something to offer Germany in this area. For example, despite U.S. strong warnings, Germany has not refused to work with Huawei and allowed it to build $5 \mathrm{G}$ networks on its territory for fear of falling hopelessly behind in the technology race.

The Belt and Road Initiative, including its digital dimension (announced by President Xi at the opening of the Belt and Road Forum on May 14, 2017), has not been officially supported by the German government. But in July 2018, Merkel, who sees herself as the leader of the EU-China dialogue, initiated, at a summit with the same name, the signing of a memorandum of understanding between the 
European Investment Fund and China's Silk Road Fund (European Commission, 2018). On the one hand, the German chancellor thus demonstrated her commitment to pan-European unity, but, on the other hand, her initiative has in fact become a major step in supporting the infrastructure project as such.

In the short term, economic interests are likely to continue to shape Germany's foreign policy towards China. Since these countries have significantly different views on strategic political values, German politicians have to pay increasingly more attention to the issue of values when it comes to dealing with China (Poggetti, Shi-Kupfer, 2018, p. 42).

According to the theory of constructivism, a state can cooperate with or, on the contrary, perceive another state as a rival or even an enemy, depending on how it perceives its identity. In this respect, China has a dual identity for Germany. And yet, their bilateral cooperation seems predestined to keep expanding, even if this may be at odds with the commitment to pan-European values.

\section{FRANCE}

The relations between China and France, characterized since 2004 as a "global strategic partnership," also revolve around trade and economic cooperation. For example, in 2018 bilateral trade increased by a record $15.5 \%$ to $\$ 62.9$ billion, while imports from France to China rose by $42.2 \%$.

According to the constructivist approach, the influence of statesmen on global processes can play a crucial role, as social structure and personality are subject to mutual construction (Alekseeva, 2014, pp.4-21).

In this respect, President Macron's example is quite indicative. Having sensed the wind of change, he proved to be a more ardent supporter of values transformation than his other colleagues. His rhetoric recently has demonstrated the primacy of practical gains over traditional European values, which in fact originated in France. His proposal to invite Russia back into the Group of Seven pushes the important issue of values shared by the G7 countries into the background and appears to be quite in line with Trump's "business first" approach. There are many such precedents. For example, N. Litvak analyzes official Paris' behavior with regard to events in Yugoslavia 
that ended in its collapse, and in Tunisia after the beginning of the Arab Spring, which clearly contradicted French and European ethical principles that were sacrificed to short-lived political objectives (Litvak, 2018, pp.163-172).

His remarks at a meeting with the French ambassadors immediately after the Biarritz summit reaffirmed Macron's readiness to not only join in the transformation of European values to adapt them to the public demand and the international situation, but also use this process in order to become the European Union's ideological leader, taking over from Merkel.

At the same time, Chinese officials speak openly about the problems facing France, as well as the political economic, demographic, and social difficulties in Europe as a whole, contrasting Europe with China, where the situation is much better in this respect. The communications strategy which highlights Europe's weaknesses has been stepped up recently to claim that "the Western world is plagued with populism" (Xinhua, 2016), thus indicating Beijing's ambitions to propose new principles of the world order.

France does not officially support the Belt and Road project, obviously trying to bargain for economic benefits for itself and, at the same time, moderate China's appetite. For China, Paris is clearly of interest, as it is the second largest economy in the European Union and a state with major seaports. The question is how long the French leadership will be able to officially ignore the Chinese initiative, given the latest trends in its foreign policy discourse.

\section{ITALY}

The ruling circles are too preoccupied with a never-ending political crisis in the country and its depressed economy to philosophize on panEuropean values. The popularity of the League and its strict migration policy demonstrates perfectly that traditional democratic values have outlived themselves and no longer meet public demand. The main political asset of Matteo Salvini, who represents the opposition and the main threat to the "left-wing" stability of the Italian political system, is his refusal to accommodate migrants by closing Italian ports to 
them. A large part of Italian society no longer accepts "equality and brotherhood" as the basis of pan-European values, realizing that the altruistic approach to foreign refugees in need of help hits Italians in the pocket, and in many ways, as Salvini constantly points out, represents manipulation by third parties (Salvini, 2017).

Another event indicating the primacy of practical gains over the commitment to European solidarity was the signing on March 22, 2019 of a memorandum sealing Italy's accession to the Belt and Road Initiative. China had managed to convince Italians that the project would bring them economic benefits and that Beijing did not pursue any political ambitions. This is exactly how then Minister of Economic Development, Labor and Social Policy Luigi Di Maio commented on the move (Di Maio, 2019).

From the point of view of constructivism, in the system of international relations identity is created in the process of interaction between actors. At the same time, it denies the original existence of values per se, for they, too, like identity, are formed in the process of communication (Pavlenko, 2015, pp.53-66).

EU states, and Italy in particular, are in the process of exploring their own identity, based on their relations with China. There is no doubt that it is this vector of Italian foreign policy that will largely determine its position and the perception of the international system by other actors in the future.

According to Brussels, cooperation with Beijing carries a lot of risks for Rome, but trade and investment relations have recently been playing into China's hands. The government of Italy, whose weight in the European Union can hardly compare with that of Germany or France, has opted for prospective economic gains, being practically the first in the Group of Seven to have become part of China's global project at the official level.

\section{THE EUROPEAN UNION}

Even though China is the European Union's second largest trading partner after the United States, Brussels is very cautious about China. In the "EU-China: A Strategic Outlook" published by the European 
Commission on March 12, 2019, China is openly referred to as "an economic competitor in the pursuit of technological leadership, and a systemic rival promoting alternative models of governance" (European Commission, 2019).

The "weak point" of the liberal values system as the basis of the EU's identity is that even its "major countries" give priority to their own economic gains, which makes the European Union's policy towards China fragmented, thus emasculating the most important instrument of foreign policy discourse, that is, the liberal idea.

Broader cooperation and stronger mutual influence between the European Union and China seem inevitable. Although it is easier for Beijing to build relations with EU member states on a bilateral basis, it will not be able to ignore Brussels and its policies. Given the economic benefits of cooperation with China, including those promised by the Belt and Road Initiative, it is likely that the fading liberal values will keep eroding further.

The EU's more pragmatic policy towards China has recently demonstrated its willingness to develop constructive interaction which nevertheless does not help strengthen and spread liberal values. The EU is facing the need to continue economic and geopolitical cooperation with China without formally abandoning its traditional values. But the rise of support for populist parties in EU member states, as well as their intention to engage with China one-on-one, including through the Belt and Road Initiative, may signify the EU's turn to a less principled policy, indicating the priority of national interests over common ones.

The European Union positions itself as "normative power," the concept of which defines its international identity. According to this concept, the main goal of its foreign policy is precisely the promotion of liberal values around the world.

T. Ruhlig believes that China's fundamental one-party political values rarely find understanding in EU institutions which are dominated by a skeptical, if not anti-Chinese, attitude. And this is not just about rejecting China's authoritarian model, but also about fearing that Beijing's increasing political, economic, technological, 
and ideological strength is a challenge to Western dominance (Ruhlig, 2018, p.95).

The "EU-China 2020 Strategic Agenda for Cooperation" demonstrates not only their high degree of interdependence, but also their determination to deepen cooperation, as evidenced, in particular, by their intention to conclude a comprehensive investment agreement in 2020, despite the fact that China appears as a "strategic opponent" in the EU official discourse.

In the process of communicating with Beijing, which will only intensify, the EU's international identity will be changing. The shaken system of liberal values has already embarked on a path of transformation, and it will continue to change due to many factors, including the influence of China's competing collective values.

We are witnessing the emergence of a new reality. One of its key features is the transformation of pan-European values and the liberal idea in its widest sense. It is obvious that not only can this idea not be universal, but it is not effective even in the West.

This trend has clearly been sensed in Russia and was articulated by President Vladimir Putin in an interview with the British Financial Times in June 2019: “There is also the so-called liberal idea, which has outlived its purpose. Our Western partners have admitted that some elements of the liberal idea, such as multiculturalism, are no longer tenable" (Putin, 2019).

While talking about the collapse of the liberal idea, Ivan Krastev, however, does not see China as the flagship of a system of universal values for the whole world but views Beijing's behavior as being motivated solely by economic pragmatism free of any ideology-laden foreign policy objectives (Krastev and Holmes, 2019b).

Although Brussels insists that EU member states adhere to a consolidated policy towards China, and Merkel and Macron still stand united in calling for working out rules of conduct with regard to China that would be optimal for all member states, the case of each of the EU founding countries, considered separately, shows that the main 
unifying factor of the most prominent integration phenomenon of our time is in great, if not deadly, danger.

Having analyzed the attitude of the most economically advanced countries towards China from the point of view of constructivism, we can conclude that the perception of China's identity by these countries will be changing in the process of communication. For example, China appears in a negative light in UK discourse for a number of reasons, including the influence of external factors (such as the change of U.S. policy towards China). The same is true of Germany which views China's identity dually: on the one hand, Beijing is an essential economic partner, and on the other hand, it is a threat to the liberal system of values that has obviously already lost its position as a universal model not only for the world, but even for Europe. France is drawing on discursive power and has every chance of leading the way in transforming European values, largely due to Macron's personality. His foreign policy discourse demonstrates a new perception of China's identity in Europe. Italy has been making it clear to Europe that it intends to step up cooperation with Beijing in the hope of solving its own economic problems, at least partly, thus pushing the issue of values to the sidelines. Italy's identity will probably undergo greater changes in the process of communication with Beijing than that of Great Britain, Germany or France. As for the European Union, it will find it increasingly hard to implement its main foreign policy task. The interdependence of the EU and China will increase and so will the influence of China's collective values, an important discursive instrument of its foreign policy, on Brussels.

The future of the liberal idea as the basis of the European Union and its main foreign policy instrument will depend significantly on whether its countries are able to pursue a consolidated policy with regard to China. If the EU adopts a common approach towards China in the near future, one can say that European values (albeit slightly modified) will remain relatively effective. Otherwise, attempts to solve domestic socioeconomic problems can exacerbate contradictions within the EU, and its member states' bilateral relations with China will deliver a heavy blow to its integrity. 
So Russia, faced with sanctions and pressure from the European Union, could borrow China's practice of building bilateral relations with EU member states, placing emphasis on the economic benefits such interaction can produce.

\section{References}

Alekseeva, T., 2014. Myslit' konstruktivistski: otkryvaya mnogosloinyī mir [Thinking in a Constructive Manner: Discovering a Polyphonic World]. Sravnitel'naya politika [Comparative Politics], 1(14).

Alekseeva, T., 2010. Politicheskaya teoriya kak "praktichnoe znanie" [Political Theory as "Practical Knowledge"]. Sravnitelnaya politika [Comparative Politics], 4(13).

China and the Rules-Based International System, 2019. House of Commons Foreign Affairs Committee. 26 March [online]. Available at: $<$ https://publications. parliament.uk/pa/cm201719/cmselect/cmfaff/612/612.pdf $>$ [Accessed 12 February 2020].

Di Maio, L., 2019. Andare Avanti, ma con l'intellegenza [Go Ahead with Intelligence]. Il Blog delle Stelle, 16 March [online]. Available at: <https://www. ilblogdellestelle.it/2019/03/andare-avanti-ma-con-intelligenza.html $>$ [Accessed 12 February 2020].

European Commission, 2018. EU-China Summit: Deepening the Strategic Global Partnership. 16 July [online]. Available at: <https://europa.eu/rapid/pressrelease_IP-18-4521_en.htm> [Accessed 12 February 2020].

European Commission, 2019. EU-China Strategic Overview. 16 March [online]. Available at: <https://ec.europa.eu/commission/sites/beta-political/files/ communication-eu-china-a-strategic-outlook.pdf $>$ [Accessed 12 February 2020].

Grachikov, E., 2019. Strategiya partnerskih otnosheniī KNR: praktika i ee kontseptualizatsiya (1993-2018 gg.) [Partnership Strategy of the PRC: Practice and Its Conceptualization in 1993-2018]. Mirovaya ekonomika i mezhdunarodnye otnosheniya [World Economy and International Relations], 63(3).

Krastev, I. and Holmes, S., 2019a. How Liberalism Became "the God That Failed" in Eastern Europe. The Guardian, 24 October [online]. Available at: $<$ www.theguardian.com/world/2019/oct/24/western-liberalism-failed-postcommunist-eastern-europe $>$ [Accessed 12 February 2020].

Krastev, I. and Holmes, S., 2019b. Imitatsiya i nedovol'stvo [Imitation and Resentment]. Rossiya v global'noi politike [Russia in Global Affairs], 17(4), 
28 August [online]. Available at: $<$ https://globalaffairs.ru/number/Imitatciya-inedovolstvo-20176> [Accessed 12 February 2020].

Litvak, N., 2010. K voprosu o klassifikatsii kontseptsii informatsionnogo obshchestva [On the Classification of the Information Society Concept]. Sotsiologicheskie issledovaniya [Sociological Studies], 8.

Litvak, N., 2018. Sovremennaya diplomaticheskaya sluzhba kak refleksivnyī institut [Modern Diplomatic Service as a Reflexive Institute]. Polis. Politicheskie issledovaniya [Polis. Political Studies], 2. DOI: 10.17976/jpps/2018.02.12

Lomanov, A., 2015. Obshchiī znamenatel' natsii. [Common Denominator of the Nation]. Rossiya v global'noi politike [Russia in Global Affairs], 13(5), 14 October [online]. Available at: <https://globalaffairs.ru/number/Obschii-znamenatelnatcii-17750> [Accessed 12 February 2020].

Macron, E., 2019. Address to the Ambassadors. Inosmi.ru, 28 August [online]. Available at: <https://inosmi.ru/politic/20190828/245721003.html $>$ [Accessed 12 February 2020].

Merkel, A., 2018. Rede von Bundeskanzlerin Merkel zur Eröffnung der Hannover Messe am 22. April 2018. Die Bundeskanzlerin, 22 April [online]. Available at: <https://www.bundeskanzlerin.de/bkin-de/aktuelles/redevon-bundeskanzlerin-merkel-zur-eroeffnung-der-hannover-messe-am-22april-2018-1007284> [Accessed 12 February 2020].

Ministry of Foreign Affairs, 2002. Tasks of German Foreign Policy: East Asia. May [online]. Available at: <https://www.auswaertiges-amt.de/blob/231800/7 56f9f7a0ea08ba707759d3b052e6682/konzeptostasien-data.pdf> [Accessed 12 February 2020].

Patron, C., 2019. China-UK Relations. Where to Draw a Border between Influence and Interference? Royal United Services Institute for Defense and Security Studies.

Pavlenko, V., 2015. Konstruktivistskī̄ podhod. Vozmozhnosti i predely. [Constructivist Approach. Possibilities and Limits]. Mezhdunarodnye otnosheniya. Politicheskie i sotsiokul'turnye aspekty [International Relations. Political and Sociocultural Aspects].

Pestsov, S., 2017. Diskursivnaya sila vo vneshnei politike Kitaya: interpretatsiya i prodvizhenie initsiativy 'Odin poias, odin put” [The Discursive Power in China's Foreign Policy: Interpretation and Promotion of the "One Belt, One Road" Initiative]. Izvestiya Irkutskogo gosudarstvennogo universiteta [News of Irkutsk State University]. 
Poggetti, L. and Shi-Kupfer, K., 2018. Germany's Promotion of Liberal Values vis-a-vis China: Adapting to New Realities in Political Relations. Political Values in Europe-China Relations. Mercator Institute for China Studies.

Pomozova, N., 2018. Otrazheniie vneshnepoliticheskogo vectora v discurse dokladov na XV-XIX s"ezdah Kommunisticheskoi partii Kitaia [The Reflection of the Foreign-Policy Vector in the Discourse of Reports at the XVth-XIXth Congresses of the Chinese Communist Party]. Gosudarstvennoe i munitsipal'noe upravlenie. Uchenye zapiski [State and Municipal Government. Academic Notes], 6.

Putin, V., 2019. 27 June [online]. Available at: <http://kremlin.ru/events/ president/news/60836> [Accessed 12 February 2020].

Ruhlig, T., 2018. Political Values in EU-China Relations: Towards a "Principled" or a "Pragmatic" Approach? Political Values in Europe-China Relations. The Swedish Institute of International Affairs.

Salvini, M., 2017. Migranti, Salvini accusa: "Ce' un dossier dei servizi su scafistiOng, il governo lo renda pubblico". [Migrants, Salvini accuses: "There is a dossier of services on smugglers-NGOs, the government makes it public."]. La Repubblica, 30 April [online]. Available at: <https://www.repubblica.it/ cronaca/2017/04/30/news/ong_migranti_salvini_dossier-164301374/?refresh_ ce> [Accessed 12 February 2020].

National Security Strategy, 2015. National Security Strategy and Strategic Defense and Security Review (UK). November [online]. Available at: <https://assets. publishing.service.gov.uk/government/uploads/system/uploads/attachment data/file/478933/52309_Cm_9161_NSS_SD_Review_web_only.pdf> [Accessed on 12 February 2020].

Summers, T., 2018. UK-China: Broadening the Values Agenda. Political Values in Europe-China Relations. Chatham House.

Wendt, A., 1992. Anarchy Is What States Make of It: The Social Construction of Power Politics. International Organization, 46 (2).

Wu, Xiangdong, 2017. Bianhua shijie zhong de jiazhiguan - jiazhi zhexue guozi luntan [Values in a Changing World. International Forum of Philosophy of Values].

Xinhua News Agency, 2016. The Western World Is Overwhelmed by Populism. 02 November [online]. Available at: <http://en.people.cn/n3/2016/1102/c900009136308.html $>$ [Accessed 12 February 2020]. 